\title{
CENAS (IM)PRÓPRIAS PARA CRIANÇAS?
}

\author{
Maria Silvia Pinto de Moura Librandi da Rocha*
}

RESUMO: O tema deste artigo é o anime japonês Dragonball $\mathrm{Z}$ e os modos como meninos - fấs de grupos socioeconômicos díspares - produziram significações sobre ele. Propõe-se (1) colocar em evidência dois eixos temáticos que constituem esta narrativa: "lutar-agredir" (certamente sua face mais visível) e "cuidarproteger", a partir das relaçōes entre três personagens - Goku, Gohan e Piccolo (em suas posições de pai, filho/discípulo e mestre, respectivamente), (2) analisar os valores que são veiculados nestas relaçōes e (3) dar voz às leituras e produções de significações feitas por algumas crianças sobre estes eixos e valores. Pretende-se, a partir disso, levantar hipóteses sobre: (a) as razōes que fizeram de Dragonball $\mathrm{Z}$ um sucesso da mídia televisiva e (b) os efeitos da posiçáo dos adultos (e, em especial, dos educadores) de qualificarem esta produção (e/ou outras similares) como imprópria(s) para a infância, a priori.

Palavras-chave: Infância. Animes japoneses. Educação.

\section{(IM)PROPER SCENES FOR CHILDREN?}

ABSTRACT: The topics of this work are the Japanese anime Dragonball $\mathrm{Z}$ and how its fans - boys from different social and economical communities - built meaning about it. The proposal is (1) to discuss the two main themes of the narrative: fighting and attacking (certainly its most visible feature), and caring and respecting, which can be observed in the relationship among three characters Goku, Gohan and Piccolo (in their roles as father, son/disciple, and

Doutora em Educação e professora e pesquisadora da Pontifícia Universidade Católica de Campinas (PUC-Campinas). E-mail: silrocha@uol.com.br 
master, respectively); (2) to analyze the values conveyed in these relationships, and (3) to give voice to some children's reading and construction of meaning about these themes and values. Considering the above, this work intent to bring hypothesis about (a) the reasons why Dragonball $\mathrm{Z}$ is a television hit and (b) the effects of adults' position (especially educators) in considering this show improper for children, a priori, will be raised.

Key words: Childhood. Japanese animes. Education.

\section{Introdução}

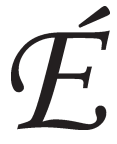

importante esclarecer, desde o início, que não há, no trabalho aqui apresentado, intenção de responder de modo direto e/ou categórico à interrogação colocada em seu título, sobretudo pelo fato de que a fundamentação teórica aqui adotada ancora-se em Bakhtin e nos conceitos de dialogia, polissemia, intertextualidade e compreensão ativa valorativa. As argumentações e análises que serão apresentadas estão, portanto, comprometidas com as teses sobre a complexidade e pluralidade dos processos de leitura de quaisquer textos, o que impede, por princípio, classificá-los quando extraídos dos processos concretos de produção de significações. A pergunta inaugural está posta pela necessidade de assumir que o tema do artigo - o anime Dragonball Z (DbZ) - é uma produção polêmica, frequentemente geradora de leituras e apreciações antagônicas, polarizadas entre o rechaço (geralmente por parte de adultos) e a adesão a seu texto (por um grande número de crianças e jovens telespectadores).

Durante o período em que DbZ esteve mais em evidência - nos anos finais da década de 90 do século XX e nos anos iniciais do século XXI, o contato com vários meninos (experts nesta saga oriental) e com vários adultos (pais, mães e professoras que, em geral, conheciam apenas fragmentos dela) permitiu compreender que, sem dúvida, tratavase de um produto cultural que tinha forte impacto nas relações intergeracionais. Os meninos diziam que:

"É um desenho diferente, que fala sobre os personagens do Bem e do Mal que lutam, a história vai de geração em geração... É muito legal, bem emocionante". 
"As lições de amizade que tem no desenho, eu acho importante".

"Eles são superunidos, conseguem superar seus próprios poderes".

Em contrapartida, nas escolas, nos grupos familiares, na mídia escrita, era corriqueiro encontrar adultos dizendo, por exemplo:

"Do pouco que vi, assisti sobre esses desenhos japoneses, não me agradou em nada. Violento demais, personagens com nomes complicados. Estão sempre em situação de luta e ainda não consegui entender se é o Bem contra o Mal, pois, pelo que percebi, lutam todos entre si. Em conversas, ouvi dizer que os bonequinhos estão sempre se lamentando, parece que estão sempre chorando ou resmungando, o que acredito que gera uma sensação de stress e infelicidade em quem assiste, no caso, as crianças". (Texto de uma professora de educação infantil, 2004)

“(...) a boa notícia a ser dada aos pais e educadores é que a febre Pokémon está terminando; a má notícia é que outra doença se aproxima, talvez de gravidade maior, cujo nome é Dragonball. (Meneghini, 2001; texto publicado na Folha de S. Paulo)

Como se pode depreender destes excertos, as reações e produções de significações sobre DbZ foram marcadas por cores fortes: paixão e fidelidade de muitas crianças, por um lado, considerando este anime como adequado para assistirem, e desconcerto, aversão, desgosto dos adultos, por outro, considerando o desenho como impróprio para as crianças.

$\mathrm{Na}$ minha posição de adulta, professora e pesquisadora interessada em estudar e compreender as condições culturais, sociais e históricas em que as infâncias e as crianças se constituem, era praticamente impossível passar por esta discussão sem me sentir desafiada a compreendê-la melhor. A pergunta central que me fazia era: Por que as crianças foram "capturadas" de modo tão intenso e tão generalizado por esta produção? Foi esta questão que orientou o início de meu trabalho de doutorado (Rocha, 2005). A partir de sua formulação, mostrou-se indispensável conhecer melhor a própria produção e os vários textos secundários (Fiske, 1987) que circularam entre seus fãs e consumidores: revistas, álbuns, sites na internet, cards, games, mangá, fitas em VHS, filmes para o cinema, entre outros. Estes textos compuseram um "pacote multimídia”, entrelaçando diversos produtos e, de certo modo, "borrando" as margens sobre os diversos tipos e formas de circulação destas produções (Buckingham, 2000). A partir destes investimentos, 
foi se tornando possível penetrar naquilo que me parecia, inicialmente (como para quase todos os adultos), um conglomerado non-sense de socos, gritos e gemidos, a fim de construir as condiçôes necessárias para entrevistar as crianças e buscar respostas para a questão colocada. Algumas das características de $\mathrm{DbZ}$ serão apresentadas a seguir, trazendo informações que permitam compreender a materialidade textual a partir da qual as crianças produzem significaçóes sobre o anime.

\section{Dragonball Z: uma saga longa, lenta e complexa}

DbZ é um anime japonês, de autoria de Akira Toriyama, nascido em 1955, em Nagoya, quarto centro urbano mais populoso do Japão e polo econômico da região central deste país. ${ }^{1}$ Iniciou sua carreira em 1978, produzindo mangás, ${ }^{2}$ entre os quais a famosa série Dragonball (escrita ao longo de 11 anos, de 1984 a 1995), composta por 42 volumes, com cerca de duzentas páginas cada um. A produção do anime para a televisão (a partir do mangá) manteve o texto original e a mesma característica quanto à extensão. Dragonball é estruturado em três sagas: Dragon Ball, Dragonball $Z$ e Dragonball GT. A saga Z (objeto específico de análise neste artigo) compõe-se de 291 capítulos.

A produção dos textos para a televisão começou a ser feita em 1986 e foi lançada primeiramente no Japão, neste mesmo ano. No Brasil, os episódios começaram a circular no canal de televisão aberta SBT, dez anos depois, em 1996; esta primeira apresentação durou apenas alguns meses, pois foi um fracasso de audiência. Somente em 1999, Dragonball ganhou espaço sistemático de exibição, no canal por assinatura Cartoon Network e na Rede Bandeirantes de Televisão. DbZ continua sendo exibido no canal pago Cartoon Network, mas em horários bem pouco nobres: em 2008, sua apresentação ocorreu de terças a sextas à 01:00 da madrugada e aos sábados, às 02:00.

A enorme extensão desta produção é protagonizada por número também bastante grande de personagens: são 81 personagens importantes, identificáveis em suas relaçôes de pertença aos clássicos domínios do Bem e do Mal. A profusão de personagens secundários regulares e de outros que participam de poucos episódios é tão grande que não há condições de enumerá-los. 
Os episódios que compõem as sagas são interrelacionados, sendo os posteriores continuação dos que os antecedem. No começo de cada capítulo insere-se (através de um narrador) uma breve contextualização do que aconteceu antes, deixando entrever a vinculação e continuidade entre eles. Aquilo que se fez no passado é muitas vezes retomado, define posições e precisa ser conhecido para que se compreendam enunciados, ações, alianças e estratégias dos personagens. Contudo, a linearização dos textos no eixo temporal nem sempre é constituída por uma sucessão de fatos organizados em passado-presente-futuro. Não é incomum que os episódios sejam estruturados de forma menos convencional e que fatos ocorridos no passado só sejam apresentados muito à frente. Além disso, em DbZ, podem coexistir diferentes planos temporais e personagens do futuro interferem na trama, no presente. ${ }^{3}$

Ao longo das séries, operam-se modificações físicas e psicológicas nos personagens e nas relações entre eles. As mudanças de ordem física (na aparência, na quantidade de energia interna [KI] que os personagens principais têm, nos golpes que aprendem a dar) são decorrentes de treinamentos árduos (realizados, em alguns casos, sob supervisão) e por provas heroicas. Através de treinos, alguns personagens podem se transformar em supersayajins, cujo KI aumenta a cada nível. Mudanças mais complexas são as chamadas fusões, a partir das quais alguns protagonistas se fundem, surgindo deste processo um novo personagem com existência temporária. Além disso, podem ocorrer mudanças das características psicológicas de personagens, reativas a algum fato, que é explicado no enredo. Nestas circunstâncias, pode acontecer tanto a transformação de um personagem que era "do Mal" e passa a ser "do Bem", quanto o contrário. Sendo assim, se Jones (2002) tem razão ao dizer que Pokémon é um "labirinto de informações e conexões que exige muito de raciocínio", esta afirmação pode ser elevada à enésima potência quando se trata de Dragonball.

Todos os episódios terminam, invariavelmente, com um gancho de tensão: as situações de conflito são mantidas em aberto, ou quando ocorre sua solução, logo um novo problema é colocado, no interior do mesmo episódio. Em busca de alcançar seus objetivos (proteger o universo contra os personagens "do Mal”, que querem destruí-lo ou dominá-lo) os protagonistas estão sempre às voltas com a iminência do 
perigo e das lutas. Os intervalos entre os blocos também são organizados em cortes com suspense emocional, seccionando o relato no exato momento em que se forma uma tensão e quando quem o assiste mais quer (provavelmente) a continuação ou o desfecho; adia-se, ao máximo, o epílogo. Pode-se dizer, portanto, que este anime pertence ao tipo de construção teleológico com "um (ou mais) conflito(s) básico(s), que estabelece(m) logo de início um desequilíbrio estrutural, e toda evolução posterior dos acontecimentos consiste num empenho em restabelecer o equilíbrio perdido, objetivo que, em geral, só se atinge nos capítulos finais" (Machado, 2000, p. 84).

Esta orientação em direção a uma meta - fio condutor da trama - ocorre a partir de uma sucessão de confrontos entre personagens, marcados pelo uso de estratégias/golpes, da energia e força física particular de cada um e/ou pelo uso de um amuleto mágico, as esferas do Dragão (Dragon Balls). As esferas do Dragão da Terra ${ }^{4}$ são sete bolas mágicas de cristal que estão espalhadas pelo planeta e que possuem estrelas no seu interior (de uma a sete). Quando todas são reunidas, se o portador souber as palavras mágicas, pode usá-las para invocar o dragão Sheng Long, que realiza um desejo (embora existam limites para o que pode ser pedido). Depois de o desejo ser concedido, as bolas transformam-se em pedra e espalham-se novamente, não podendo ser usadas antes que se complete um ano. Peças fundamentais no início de DbZ, no decorrer da série as esferas passam a ser secundárias. Em seu lugar, ganham importância as técnicas de artes marciais, o aperfeiçoamento físico e mental, o aumento e o domínio do KI. A perícia para utilizar esta energia permite concentrá-la em qualquer parte do corpo, o que torna possível o uso de determinadas técnicas, como o Kame Hame Ha, uma das mais importantes e poderosas nos duelos. Entre o uso do amuleto mágico e o esforço pessoal e coletivo incessante para superar os limites, é esta segunda alternativa que vai ganhando destaque crescente e passa a ser o caminho mais frequentemente determinado pelo autor do anime aos personagens, para o enfrentamento de seus opositores e dos desafios que lhes são apresentados.

$\mathrm{O}$ ritmo das imagens em $\mathrm{DbZ}$ é extremamente vagaroso, inclusive nas situações de luta. Nestas, os personagens ficam imobilizados na tela, em suas posições dos golpes e/ou da recepção deles, por vários segundos. O único movimento é o de nuvens que passam por 
trás deles, num esforço do autor para produzir efeito de movimentação, usando recursos que podem ser considerados bem rudimentares. Estas imagens são apresentadas por um tempo muito mais expandido do que o necessário para "lê-las", em especial para "leitores" experientes que costumam acompanhar o desenho. De um modo geral, DbZ é lentíssimo e as lutas são mais significativamente representadas pelos traços duros e impactantes do desenho do que pela movimentação.

As análises do material permitiram identificar que o anime compõe-se de tópicos tematizados predominantes (ou temas, conforme Maingueneau, 1997), organizados em torno de formas contraditórias de relações entre os personagens: lutar/agredir e cuidar/proteger. A seguir, cenas recortadas de um episódio de $\mathrm{DbZ}$ permitem-nos trabalhar com estes tópicos.

Cenas para análise: as relações entre Goku, Gohan, Piccolo e Raditz

O episódio do qual foram extraídas as cenas tem por título "Piccolo apresenta sua melhor cartada. Gohan é um menino chorão". O cenário principal em que se desenrola o desenho é uma área desértica e desabitada. No início do episódio, Goku (principal personagem da saga) dirige-se para esta área, para salvar seu filho Gohan, sequestrado e ameaçado de morte por Raditz, (irmão de Goku e, portanto, tio de Gohan). Gohan é um menino de 6 anos, neste ponto da saga filho único do casamento de Goku com Chichi; é alegre e brincalhão, mas também muito chorão e bastante escandaloso quando se encontra em situaçôes de dificuldade. É excelente aluno, atributo decorrente dos sistemáticos esforços de sua mãe, para quem a escolarização e os estudos são valores de grande importância. A intenção de Raditz ao sequestrar Gohan é convencer Goku a voltar a ser um sayadjin "do Mal", propondo unirem suas forças para destruírem a Terra e dominarem o universo. Participam deste episódio, como aliados de Goku, Piccolo, Kulilin, Mestre Kame e Bulma. Os três últimos são amigos fiéis, parceiros indispensáveis na luta contra o Mal, e simbolizam a aliança entre amizade do coetâneo (Kulilin), sabedoria dos idosos (Mestre Kame) e inteligência feminina (Bulma). Já Piccolo, personagem irascível e antipático, inimigo de Goku, torna-se seu aliado temporário, apenas para enfrentar Raditz, anunciando que, tão logo matem este inimigo comum, Goku será sua próxima vítima. 
A luta que se desenrola é intensa, marcada por agressões verbais e físicas/imagéticas: personagens são atirados ao ar e despencam no chão, Piccolo tem seu braço esquerdo quase totalmente decepado por um golpe de Raditz, Gohan chora, copiosamente, dentro da nave em que foi aprisionado, por saber que seu pai é espancado pelo tio. $\mathrm{O}$ episódio termina assim: Goku está estendido no chão, semiconsciente, e Raditz pisa sobre o tórax de seu irmão e diz de modo solene e violento: "Morra, Kakaroto!!”. Gohan, movido pela ira, liberta-se da nave e descobre que também tem poderes (até então desconhecidos de todos). $\mathrm{O}$ momento é de extrema tensão.

Goku é morto pelo irmão. Desta morte, resulta importante acontecimento: Piccolo assume a tutela de Gohan e, durante um ano, o treinará para que desenvolva seu KI, preparando-o para enfrentar os sayajins "do Mal".

A análise do eixo intratextual deste episódio permite evidenciar os tópicos tematizados que caracterizam a unidade semântica dos textos, já anunciados: lutarlagredir e cuidar/proteger. Estes pares opostos, eixos temáticos do anime, serão exemplificados através das relações entre Goku, Gohan e Piccolo, buscando mostrar que, se o primeiro par (lutarlagredir) é, certamente, a face mais visível da trama, não é o único valor veiculado pelo desenho.

Lutarlagredir textualiza-se de diversas maneiras, nas imagens e nas enunciaçôes verbais. Os golpes, as estratégias e ardis para derrotar o opositor, o uso brutal da força e da violência, os modos como se nomeiam/adjetivam/caracterizam ("chorão", "escandaloso", "insolente", "idiota", "maldito", "nanico", "traidor”), o cenário em que o episódio se desenrola, tudo isso estrutura um trajeto temático que, de um acontecimento a outro, marca este tópico. $\mathrm{O}$ texto tem como referência maciça o embate físico e o grau de potência/violência de seus golpes, trazendo juízos de valor implícitos, especialmente de tipo pejorativo.

Contudo, as açôes de cuidar/proteger também estão presentes, sendo, inclusive, as deflagradoras deste episódio específico. Goku envolve-se na batalha contra Raditz para proteger seu filho. É certo que sua missão não é exitosa, já que ele é massacrado pelo irmão e morre, mas o massacre e sua morte impulsionam Gohan a crescer, a descobrir em si uma força até então desconhecida, que só se revela pela motivação de proteger seu pai. Outro ponto a ser destacado é o fato de 
Piccolo assumir a tutela de Gohan, cuidando dele para que se torne um guerreiro. Esta tutela é desempenhada nos episódios seguintes com extremo rigor e aspereza, sem quase nenhuma manifestação de afeto. Gohan é muito obediente, submete-se a provas duras, aceita o longo treinamento, lembrando ao telespectador - de tempos em tempos que há uma justificativa indiscutível para esta submissão: ocupará, temporariamente, o lugar do pai como personagem principal na proteção da Terra e será peça-chave para que Goku volte a viver, muitos episódios à frente. Dessa relação entre Gohan e Piccolo, resultará uma mudança decisiva do segundo: Piccolo se transformará num personagem do Bem e isto se dará porque, pouco a pouco, resistente e muito a contragosto, Piccolo começa a gostar (quase como um pai) do pequeno Gohan. Sendo assim, o amor paternal e filial, a dedicação do mestre para fazer crescer seu discípulo e a obediência ao mestre, associada a uma posição de indiscutível respeito pelos seus conhecimentos, são também valores que compóem o quadro axiológico deste anime.

Temos, então, que o eixo cuidar/proteger constitui um tópico diferenciado no texto, embora não seja tematizado fora do âmbito da orientação para a luta, devendo ser compreendido a partir da mesma, tendo-a como referência. Contudo, o inverso também é verdadeiro e, ao se colocar a luta em perspectiva ou olhar o que está sob ela, revela-se sua meta principal: proteger, no nível mais macro, o universo; no nível mais micro, os personagens do Bem, entre si. Entretanto, este eixo é bem menos explicitado, sendo necessário enfatizar que quanto mais qualquer telespectador assista o anime, mais se deparará com a exibição de cenas de enfrentamento entre os personagens, que se materializam tanto nos momentos de ápice do enredo, quanto nas minúcias do texto. Estas considerações permitem esclarecer que existem relações hierárquicas entre os dois tópicos, sendo predominante, sem dúvida, o embate entre os personagens.

Uma indagação, então, torna-se possível: quais são as significações que crianças-fãs deste anime produzem sobre ele? A predominância do tópico lutarlagredir é decisiva para orientar suas leituras, suas preferências, seu enredamento no texto? Afinal, é/foi isto que mobili$\mathrm{za} /$ mobilizou pequenos expectadores para, dia após dia, sentarem-se à frente da televisão e, apaixonadamente, seguirem os passos desta longa e lenta trama? 
A busca de respostas para estas indagações não poderia prescindir da oportunidade de ouvir as próprias crianças. Foram, então, realizadas entrevistas individuais com meninos, fâs de $\mathrm{DbZ}$ e seguidores assíduos deste anime. Nestes encontros, feitos individualmente com cada um dos participantes, assistíamos ao episódio acima mencionado ${ }^{6}$ e íamos conversando sobre ele. A seguir, apresento os meninos.

\section{Os meninos que participaram do estudo}

Do estudo realizado participaram oito meninos com idades entre 11 e 12 anos. Para apresentá-los, optei por agrupá-los pelas semelhanças de contextos culturais, sociais e econômicos em que vivem.

O primeiro grupo é composto por Tomás, Breno, Pedro e Eduardo. ${ }^{7}$ São meninos que moram em bairros de classe média-alta de Campinas (estado de São Paulo), estudam em escola particular, têm acesso a diversos recursos para o seu lazer e a praticamente todos os materiais complementares à produção televisiva: revistas especializadas, game-boys e seus jogos mais modernos, álbuns de figurinhas, videogames, jogos de computador, sites da internet, cards; podem montar seus decks, podem alugar as fitas do desenho. Todos têm televisão com canais abertos e a cabo. Têm bom desempenho escolar, dizem que gostam de estudar; nunca foram reprovados na escola (frequentada, prioritariamente, por alunos de classe média ou média-alta). No tempo não escolar, participam de diversas atividades (basquete, aulas de violão, grupo de teatro, aulas de inglês, computação e judô).

Fernando, Wesley, Carlos e Marcos Alexandre vivem em condições bastante diferentes: moram num bairro muito pobre, resultante de uma ocupação de terras, em Hortolândia (estado de São Paulo). O bairro não tem sistema de esgoto e até pouco antes da pesquisa não tinha água encanada. As ruas são de terra, muitas delas sem iluminação. Estes meninos acompanharam os desenhos de Dragonball através de canais da televisão aberta. Wesley passou a ter televisão a cabo dois meses antes do encontro. O que eles sabem sobre os animes aprendem, fundamentalmente, na televisão e com os textos terciários (cf. Fiske, 1987), mais regularmente na conversa entre amigos. Muito raramente podem comprar figurinhas; em geral, as que têm são obtidas em pacotes de salgadinho, como brindes; não têm cards, não sabem o que são 
os decks; às vezes, leem alguma revista sobre Pokémon, em geral de um primo ou de algum amigo. Quem tem esta oportunidade refere-se a ela com orgulho. Não têm computador, nem videogame. Fernando tem um game-boy, que herdou do filho da patroa de sua mãe. Fernando e Carlos estudam na quinta série de uma escola pública, num bairro afastado; Wesley e Marcos Alexandre estudam na escola de seu bairro, porque foram retidos na quarta série. Durante o período não escolar, eles ficam, geralmente, pelo bairro mesmo; raramente vão ao centro da cidade. E bastante comum encontrá-los pelas ruas, brincando com os amigos, soltando pipa, jogando bola. Podem controlar e gerir o tempo livre e espaços que percorrem pelos bairros com bastante autonomia em relação aos pais e/ou adultos responsáveis por eles.

Constituem, portanto, grupos de crianças cujas histórias de vida, no cotidiano, vão se tecendo com diferenças marcantes, incluindo as "experiências televisivas". Das entrevistas realizadas, foram recortados os trechos em que falam sobre o que gostam no anime e em que fazem críticas à produção em foco. Serão destacados, nesta apresentação, os comentários das crianças relacionados aos eixos temáticos que apresentamos atrás. Ao serem indagados sobre de que mais gostavam no episódio, disseram:

Tomás: "As lições de amizade. Eu acho importante. Principalmente quando é pequeno. É um exemplo legal e dá um bom sentimento (...). Outro ponto legal é a parte que o Mestre Kame, a Bulma e o Kulilin estão indo em direção da batalha, pra tentar ajudar o Goku e o Gohan. Porque aprende também negócio de amizade, de confiança (...).Os efeitos especiais e a música também entra aí nos pontos positivos: bam, bam, bam... Ela estimula a ver o desenho, a gente sente mais emoção quando vê a luta e os efeitos especiais dos poderes que eles soltam".

Carlos: "Das lutas, porque mostra a persistência de querer e poder alcançar alguma coisa que ele quer muito. [O que mais gostei] Foi quando o Piccolo começa a ajudar o Goku a se salvar. E eu também gosto da luta. O Goku fica aumentando o poder e ele nunca desiste. Ele é um personagem muito forte do desenho. E o único que consegue derrotar ele é o Gohan”.

Pedro: "As lutas são bem feitas (...). São bem pensadas no enredo. No DbZ, a luta acaba sendo pra salvar o mundo. Então, acaba tendo um objetivo mais importante que o do Pokémon". 
Wesley: "A parte das lutas. Gosto quando eles dá poderes um no outro (...). A parte da luta dá pra ver quem é mais forte (...). Ah, achei também muito legal estas partes que o... Porque o filho do Goku viu que o pai dele tava quase morrendo, não vendo assim, né, vendo pela mente, que o pai tava quase morrendo, perdendo a luta e daí ele foi ajudar. Ele sai da bola, ele conseguiu superar seus próprios poderes".

Eduardo: "O legal são as lutas".

Pesquisadora: O que, mais exatamente, das lutas?

Eduardo: "Ah, as lutas mesmo".

Fernando: "No DbZ, eu gosto da parte que aparece a Bulma. Porque é assim: o Goku usa a força e a Bulma usa a inteligência. Então eu acho mais legal. [Gosto] Quando o Goku perde a batalha. Porque é assim: se você assistir qualquer desenho, os mocinhos sempre ganham [fala com certo tom de desprezo]. O Goku, não. Ele perde e ganha. É mais próximo da vida mesmo, né? Na vida é assim: 'Ó, é a vida, um dia se perde, no outro se pode ganhar'. Que nem os do Bem. Eles quase morreu já, um monte de vezes".

Quando falam sobre "de que gostam nos desenhos", os meninos não se referem somente aos golpes, ao confronto. Vários outros temas são sublinhados como importantes: a persistência em busca de alcançar objetivos, a união entre os personagens, as liçóes de amizade (consideradas exemplares), as relaçôes de ajuda e de confiança entre personagens, acreditar em si próprio e, ao mesmo tempo, o valor do uso da inteligência, do esforço para se superar e de ter como projeto salvar o mundo.

Nestes casos, parece que o que importa não é apenas o que se faz na luta, mas o que ela simboliza/representa, num quadro de valores mais amplo do que simplesmente sua descrição pontual. Ou seja, falam sobre a luta, mas, em muitos pontos, destacam o que está por trás dela, em termos da história e do que representa aquele personagem enfrentar aquele outro, naquele determinado momento e circunstância.

Dos resultados possíveis da luta, vencer nem sempre é o mais valorizado. Fernando inverte totalmente as expectativas mais comuns, valoriza a derrota como metáfora da vida. Este mesmo menino confere estatuto de personagem principal à Bulma que, formalmente, ocupa 
plano secundário na trama. Poderia destacar que ela é uma jovem muito bonita, que atrai alguns personagens masculinos, ao longo da saga. No entanto, não são os atributos físicos que sublinha. Para Fernando, a inteligência de Bulma tem mais prestígio do que a força do principal protagonista de DbZ.

Entretanto, os meninos também gostam da luta, das "lutas mesmo", destacando o termo luta em seu sentido mais estabilizado culturalmente: gostam de ver os golpes, o uso e as medidas de força física, os poderes, as situações de vencer/derrotar o outro, a possibilidade de ficar muito forte, o que significa, sem dúvida, ser mais capaz de destruir fisicamente o inimigo. As lutas devem acontecer, são bem pensadas no enredo, bem feitas, oferecem momentos de tensão e suspense, apreciados pelos meninos. No entanto, o prazer em vê-las não é incondicional, acrítico e, outras vezes, algumas respostas surpreendem.

Quando apresenta suas críticas ao desenho, Tomás, o mesmo que disse que a música o faz sentir "mais emoção quando vê a luta e os efeitos especiais dos poderes que eles soltam", fala o seguinte:

Tomás: "Pontos fracos: a violência. É um ponto que marca: a violência.

Eu acho que é um mau exemplo pras crianças".

Pesquisadora: Como assim, Tomás?

Tomás: "Deixa elas violentas. Pode deixar".

Pesquisadora: Pode ou deixa?

Tomás: "Pode. Depende da criança. A criança que assiste que já é briguenta, sempre tem um briguento, né? Ele pode ficar mais briguento ainda, a televisão pode ajudar a progredir o nosso lado mau”.

Pesquisadora: Como seria isso?

Tomás: "Ser estúpidos, agressivos...”.

Pesquisadora: Explica um pouco mais.

Tomás: "É que a criança tem que ter a consciência mais forte do que o que ela vê. Ela tem que pensar antes de falar, pensar antes de agir. Tem que ter uma consciência mais esclarecida”.

Pesquisadora: $E$ isso depende do que?

Tomás: "Da criação dos pais, eu acho... do lugar... e da vida. Depende 
(...). Mas, eu acho que a responsabilidade disso é dos pais. Dos pais, do jeito que têm que controlar o filho na TV(...). Mas, eu acho que se você tá assim angustiado, estado de depressão, depressão-júnior, vamos dizer. Você vê que ninguém gosta de você, você pode ver todo mundo afastado de você, pode ser que você pense que só a TV é importante. Aí, não estuda mais, não brinca mais com os amigos, ou fica mais magro, ou fica mais gordo, não faz exercício, não come direito, acho que tudo isto interfere na vida pessoal (...). As pessoas, a família vai ter que ajudar. Os adultos, principalmente".

As escolhas de Fernando e os comentários de Tomás dão indícios de que gostar do desenho não significa seguir de modo fiel a direção dada pelo autor, tampouco avaliá-lo de modo positivo, plenamente. Elas são idiossincráticas, mas há um ponto do episódio criticado de forma unânime pelos meninos. Falando sobre o que não gostaram, dizem:

Carlos: "O Piccolo perdendo o braço. Porque eu nem sei direito porque ele perdeu o braço. Isso é sem importância nenhuma. E é muito violento".

Marcos Alexandre: “(...) até o Raditz cortou o braço do outro, lá... eles tinha que falar que não tem que fazer isso, que num deve cortar o braço do outro. Não precisava ter esta parte".

Eduardo: “(...) acho que também a parte que o Piccolo perde o braço, nada a ver. Porque eles exageraram na violência e porque depois ele consegue reconstruir, ele é de uma raça que recupera as partes do corpo. Então, eu acho que fica demais de violento, pra nada".

Fernando: "[Não gostei quando] Arranca o braço do Piccolo (...). Porque é um exagero de violência. Não é legal”.

Pedro: "E [não gostei] quando o Piccolo perde o braço".

Pesquisadora: Por quê?

Pedro: "Não... é que... sei lá, do nada aparece ele sem um braço, sabe, de repente ele fica sem um braço e continua, como se nada tivesse acontecendo, tudo super normal...? Só perdeu um braço!!! É demais, né? Eu acho uma coisa violenta gratuita".

Tomás: "Tiraria também o Piccolo perdendo o braço, porque é meio chocante, eu não gostei deste ponto".

Wesley: "[Não gostei] Foi aquela parte que o Piccolo perdeu o braço. Que o Goku conseguiu desviar e o Piccolo tentou desviar, mas não deu e pegou o braço dele. Achei que ficou ruim. Ah, não sei explicar direito... acho 
ruim (...). Não teria esta parte, se eu fosse o autor... deve ser ruim ficar só com um braço, né?”.

Breno: "[Não acho legal] Aquela hora que o Piccolo fica sangrando, aquela hora lá que o cara tava quase matando o irmão... Ah, é chato ver um negócio desses (...). Nossa, dá uma sensação assim [encolhe os braços]. Ruim. Nossa, eu senti assim... nossa!! [põe as mãos no pescoço]. O que vai acontecer, eu pensei. O que que vai acontecer?!?! Daí... acabou!!! Ficou horrível!!! Dá uma sensação meio de ai... de sufoco".

A cena em que Raditz fere Piccolo, arrancando-lhe um braço, é problematizada de modo radical. Da perspectiva destes meninos, nem toda ação é justificável, inclusive algumas que são nevrálgicas para a estruturação da narrativa. Voltar ao desenho para buscar pistas que ajudem a entender este consenso entre as crianças (mais intrigante ainda quando se percebe que eles analisaram o episódio individualmente) não parece ajudar muito.

Como Eduardo lembra bem, Piccolo é de uma raça que se regenera e, portanto, tudo se acertará depois. Mas, para Eduardo, este é o argumento que usa para avaliar esta situação como desnecessária. Não há nos enunciados verbais ou expressões faciais diferenças/marcas decisivas em relação a outras situações de luta, que indicassem dor maior ou sofrimento extremo, por exemplo. Goku lamenta o que ocorreu, mas também não dramatiza. Goku diz: "Droga! Você está bem, Piccolo?”. Piccolo está sem um braço, sangra, geme brevemente, mas não se abate: "Não se preocupe, mesmo sem um braço eu não me renderei, e continuarei lutando". Ninguém se opõe. Ninguém recrimina. A luta continua.

Portanto, as interpelações, oposiçôes e recriminações das crianças não são paráfrases do texto; vêm de outras instâncias. A adesão das crianças às situações de agressão não é incondicional, mas os critérios que usam para isto não são previsíveis/clarificáveis por análises formais do texto. Seria mais compreensível se as oposiçóes à violência estivessem relacionadas a personagens carismáticos e com grande importância afetiva para os meninos. Todavia, não é isso que acontece sempre: não toleram Piccolo sem o braço, mas, com exceção de Breno, não se opõem à violência de Raditz em relação a Goku, que termina morto. É a imagem da falta do braço e do sangue que impactam? Entretanto, num nível descritivo, a imagem da cena entre Raditz e Goku dificilmente seria considerada menos violenta: Raditz pisoteia o tórax de Goku, que está caído no chão, 
semiconsciente, e diz: "Morra, Kakaroto". Também não se explicam estas diferenças de posicionamento olhando-se quem comete a violência: nos dois casos, é o mesmo personagem. O que estará em jogo?

\section{DbZ: intertextos}

Os meninos interpretam os desenhos não apenas ecoando/parafraseando o que se diz/o que se aponta como importante ou o modo como se diz; interpretam problematizando, questionando. Invertem a hierarquia entre os eixos e colocam o cuidar/proteger como principal. Apresentam resistências a questôes marginais/menores, mas, também, a questões nucleares dos textos. Sugerem alterações, rejeitam frontalmente alguns aspectos e trechos. Veem possíveis consequências da violência que compóe a trama do anime. Incluem outros pontos de vista, contrapalavras, questionamentos, polêmicas.

Este material permite questionar uma forma corriqueira de se supor as relaçôes entre as crianças e a televisão, que pode ser formulada, em linguagem coloquial, da seguinte maneira: "se as crianças estão assistindo a um desenho, na televisão, de que gostam muito, há forte tendência a acharem que tudo o que está sendo apresentado é importante e adequado". Ou seja, em termos bakhtinianos, poder-se-ia supor forte tendência de que as crianças tomassem este texto como palavra autoritária, proferida por um outro de autoridade inquestionável, do tipo "se é X quem diz P, P é verdadeiro e correto". No entanto, os meninos, por vezes, dizem: "não compreendo porque X diz P", "X não deveria dizer P" e "X deveria ter dito Y".

As crianças constroem intertextos não apenas a partir de outras produções do mesmo gênero, mas também a partir de suas experiências na vida. É pela presentificação da importância das relações entre irmãos, dos pais, da amizade, da confiança entre as pessoas, da capacidade de se colocar no lugar do outro - na vida real - que tornam o texto do desenho aceitável ou não. As interpretações são atravessadas por outros fatos, por outras significações produzidas em outros contextos e em outras relações, e não unidimensionalmente pelo que está sob o controle da televisão e/ou dos autores que esta mídia faz circular.

Elas não tomam as experiências televisivas como totalmente inofensivas: deslizam em seus argumentos sobre as possibilidades de 
a televisão e seus programas afetarem de maneira negativa os modos de ser e de se relacionar das pessoas, o que mostra que não estão plenamente convencidas de que estas práticas sejam inócuas e/ou neutras. São veementes em alguns pontos ("Eles tinha que falar que não tem que fazer isso, que num deve cortar o braço do outro", ou "a televisão pode ajudar a progredir o nosso lado mau”). Este movimento é indicativo de que o outro participante das experiências cotidianas destes meninos continua sendo levado em consideração. A impressão de que, quando assistem à tevê, as crianças estão plenamente capturadas por ela é falsa, já que interpretam o que veem levando em conta as vozes (no sentido de posição axiológica) das pessoas com quem convivem. Isso nos coloca (a nós, que convivemos com as crianças) numa posição excepcionalmente importante, da qual não devemos desocupar.

Entretanto, é necessário abordar um último ponto inquietante. No material empírico da pesquisa, este outro participante refere-se, regularmente, a pessoas da família e aos amigos. Os meninos nada dizem sobre os adultos com quem convivem na escola. Não há uma só enunciação do tipo: "Minha professora disse que...", "Meu professor acha...".

Seria este silêncio resultante do fato de que assistir à televisão é uma atividade essencialmente doméstica e pouquíssimo incorporada às práticas educacionais? É uma explicação possível, mas não parece suficiente ou satisfatória. Afinal de contas, se não se assiste à televisão na escola, certamente fala-se sobre a televisão e seus programas neste contexto. Contudo, nesses diálogos, quem são os interlocutores? Se retomarmos as falas das educadoras, trazidas no início do texto, podemos dizer que as professoras, de um modo geral, não se encontram em posição favorável ao diálogo. Os modos como se referem ao que as crianças dizem nos permite suspeitar que se mantêm à margem das conversas sobre o tema. Elas não dizem "Um aluno me contou..." ou "Conversei com uma criança...". Sabem que as crianças conversam sobre os animes, entre elas, o que as faz identificar que "todas (...), ou a maioria delas, adoram esses desenhos"; mas dão pistas de que, na verdade, para as educadoras, estes dizeres assemelham-se mais a um rumor, a certo murmúrio.

Caso as professoras se aproximassem um pouco mais das conversas, é bastante provável que soubessem, por exemplo, que nos animes 
não lutam "todos contra todos", independentemente de pertencerem ao Bem ou ao Mal, e que os "bonequinhos" não "estão sempre se lamentando, chorando ou resmungando". Talvez pudessem ouvir alguns meninos dizerem que valorizam a persistência, a amizade, os bons sentimentos que "leem" nos animes, não parecendo, de forma alguma, que estes sejam valores opostos àqueles que educadores costumam assumir como importantes. Talvez, então, as educadoras pudessem colocar sob suspeita a afirmação de que as crianças que assistem a estes desenhos vivem uma "sensação de stress e infelicidade".

O fato é que os educadores tendem a se manter em posição de antagonismo em relação aos animes e de desconhecimento em relação às produções televisivas para as crianças. Não acompanham, não conhecem e/ou rechaçam a priori. As falas das educadoras fazem lembrar o que Bakhtin (1988, p. 94) diz sobre as marcas do estilo poético em contraposição à linguagem do romance: “(...) não há nada que faça sua enunciação sentir a necessidade de utilizar uma linguagem alheia, de outrem. (...) o mundo, porquanto mundo de contradiçōes e conflitos, sempre é interpretado a partir de um discurso único e incontestável”.

Esta questão ganha mais vigor se considerarmos que concepções sobre a "vulnerabilidade" das crianças-telespectadoras em suas relações com a tevê estão largamente incorporadas ao senso comum; sendo assim, é pouco provável que educadores pensem de modos muito diferentes e concebam os seus alunos como especialmente "protegidos". Será que não sentem nenhum compromisso em relação a estas questóes?

Essas considerações estão sendo feitas porque talvez possam servir para diluir (ou, ao menos, atenuar) o preconceito dos educadores em relação às produçóes de que tratamos; talvez possam servir como um ponto a partir do qual seja possível uma postura menos antagônica, por princípio, estimulando formas de compreensão sobre a aproximação das relações das crianças com elas.

\section{Notas}

1. Informações extraídas de: <http://pt.wikipedia.org/wiki/Akira_Toriyama>.

2. Mangás são histórias em quadrinhos japonesas, com estilo próprio de desenho, de traços bem peculiares. São lidos em sentido oposto aos gibis ocidentais, da direita para a esquerda, iniciando da página que, para os ocidentais, é a última. Vários mangás dão origem a animes para exibição na tevê, em vídeo ou nos cinemas; mas também ocorre o inverso e 
animes tornam-se mangás. Assim como os animes, os mangás não tematizam apenas lutas, mas também histórias de amor, futebol, entre outros temas.

3. Por exemplo, Trunks, filho de Vejita e Bulma, viajou do futuro para o presente a fim de alertar Goku sobre uma doença fatal que o atingirá e para lhe entregar um remédio que irá salvá-lo, feito por tecnologias desenvolvidas muito posteriormente.

4. Existem também sete esferas de Namokusein, que ficam espalhadas neste planeta.

5. Kakaroto é o verdadeiro nome de Goku.

6. Assistíamos também a um episódio de Pokémon, mas este material não será abordado neste artigo. Os encontros com os meninos foram videofilmados.

7. Todos os nomes são fictícios.

\section{Referências}

BAKHTIN, M. Questôes de literatura e estética. São Paulo: Hucitec, 1988. BUCKINGHAM, D. After the death of childhood. Growing up in the age of electronic media. London: Polity Press, 2000.

FISKE, J. Television culture. London; New York: Routledge, 1987.

JONES, G. Brincando de matar monstros: por que as crianças precisam de fantasia, videogames e violência de faz de conta. São Paulo: Conrad, 2002.

MACHADO, A. A televisão levada a sério. São Paulo: Senac, 2000.

MAINGUENEAU, D. Os termos-chave da análise do discurso. Lisboa: Gradiva, 1997.

ROCHA, M.S.P.M.L. Televisão, infância e animes: intertextos. 2005. Tese (doutorado em Educação) - Faculdade de Educação da Universidade Estadual de Campinas, Campinas.

TORIYAMA, A. Dragonball Z-01. São Paulo: Conrad, 2001.

Recebido em 10 de junho de 2009.

Aprovado em 20 de novembro de 2011. 